\title{
The sedimentology and palaeoecology of the Westleton Member of the Norwich Crag Formation (Early Pleistocene) at Thorington, Suffolk, England
}

\author{
A. E. RICHARDS*, P. L. GIBBARD \& M. E. PETTIT \\ *School of Geography, Kingston University, Penrhyn Road, Kingston-upon-Thames, Surrey, KT1 2EE, UK \\ Godwin Institute of Quaternary Research, Department of Geography, University of Cambridge, Downing Place, \\ Cambridge CB2 3EN, UK
}

\section{(Received 28 September 1998; accepted 29 March 1999)}

\begin{abstract}
Extensive sections in the Thorington gravel quarry complex in eastern Suffolk include the most complete record to date of sedimentary environments of the Westleton Beds Member of the Norwich Crag Formation. New palaeoecological and palaeomagnetic evidence is presented, which confirms that the Member was deposited at or near a gravelly shoreline of the Crag Sea as sea level fluctuated during a climatic ameloriation within or at the end of the Baventian/ pre-Pastonian 'a' Stage (Tiglian C4c Substage).
\end{abstract}

\section{Introduction}

The gravel quarry complex at Thorington (TM 423 728 ) is situated $8 \mathrm{~km}$ west of Southwold in northern Suffolk (Fig. 1). This paper will present details of observations in the quarry during the period from June 1994 to September 1997, which provide significant biostratigraphical and sedimentological evidence for depositional environments associated with the Westleton Beds Member of the Early Pleistocene Norwich Crag Formation.

The deposits have been exploited in two main phases. The 'north pit' (Fig. 1) was worked from 1992 until early 1995, yielding continuous faces over $50 \mathrm{~m}$ long and $10 \mathrm{~m}$ in height. However, recent exposures have been limited to smaller excavations in the 'south pit.' Our attention was drawn to this site by B. M. Funnell and D. Hallam (University of East Anglia).

A schematic log of the stratigraphy of the sediments exposed in the Thorington Pit is given in Figure 2, with more detailed facies logs in Figure 3 and lithological counts in Table 2. At Thorington, the upper parts of the Norwich Crag Formation are deformed by the development of active layer (permafrost) structures correlated with the widespread Barham Arctic Structure Soil (Murton, Whiteman \& Allen, 1995; Kemp, 1985; Rose et al. 1985a) and a later, more arid phase of permafrost conditions that occurred immediately before the deposition of glacial deposits of the Lowestoft Formation in the Anglian Cold Stage (Hart \& Boulton, 1991; Kemp, Whiteman \& Rose, 1993). The palaeoenvironmental significance of the glacial and periglacial deposits that are exposed at Thorington Pit is discussed elsewhere (Richards, in press).

* Author for correspondence: a.richards@kingston.ac.uk

\section{Late Pliocene to Early Pleistocene deposits in Suffolk}

A stratigraphical table, comparing British nomenclature with that of the Netherlands, is given in Table 1.

The earliest Pleistocene deposits that occur in northern Suffolk are the East Anglian Crags, which were deposited at the margins of the southern North Sea Basin. In the study area the Norwich Crag Formation of Funnell \& West (1977) can be distinguished from the shelly sands of the Red Crag Formation (Mathers \& Zalasiewicz, 1988; Zalasiewicz et al. 1988). The Norwich Crag Formation comprises fine- to medium-grained, well-sorted, micaceous sands with a maximum total thickness of $40 \mathrm{~m}$ (Hamblin, 1992). Gibbard \& Zalasiewicz (1988) and Zalasiewicz et al. (1991) recognized four stratigraphical units within the Norwich Crag Formation: the Chillesford Sand; the overlying Easton Bavents Clay and Chillesford Clay, which are geographically separated clay units thought to be of the same age; and the Westleton Beds (Prestwich, 1871), which are wellsorted, clast- to matrix-supported gravels dominated by well-rounded, high-sphericity, chattermarked flint pebbles and cobbles (Hey, 1967).

The lowest part of the Norwich Crag Formation, the Chillesford Sand Member, was deposited in shallow marine conditions during the Antian Stage (Gibbard \& Zalasiewicz, 1988; Hamblin et al. 1997). Sediments of this age are periodically exposed at Easton Bavents. The deposits are characterized by a temperate mixed forest flora (West, 1961), although vertebrate remains imply that open woodland was also present (Stuart, 1982). The overlying Easton Bavents Clay and Chillesford Clay members were analysed by Zalasiewicz et al. (1991), who concluded that they 


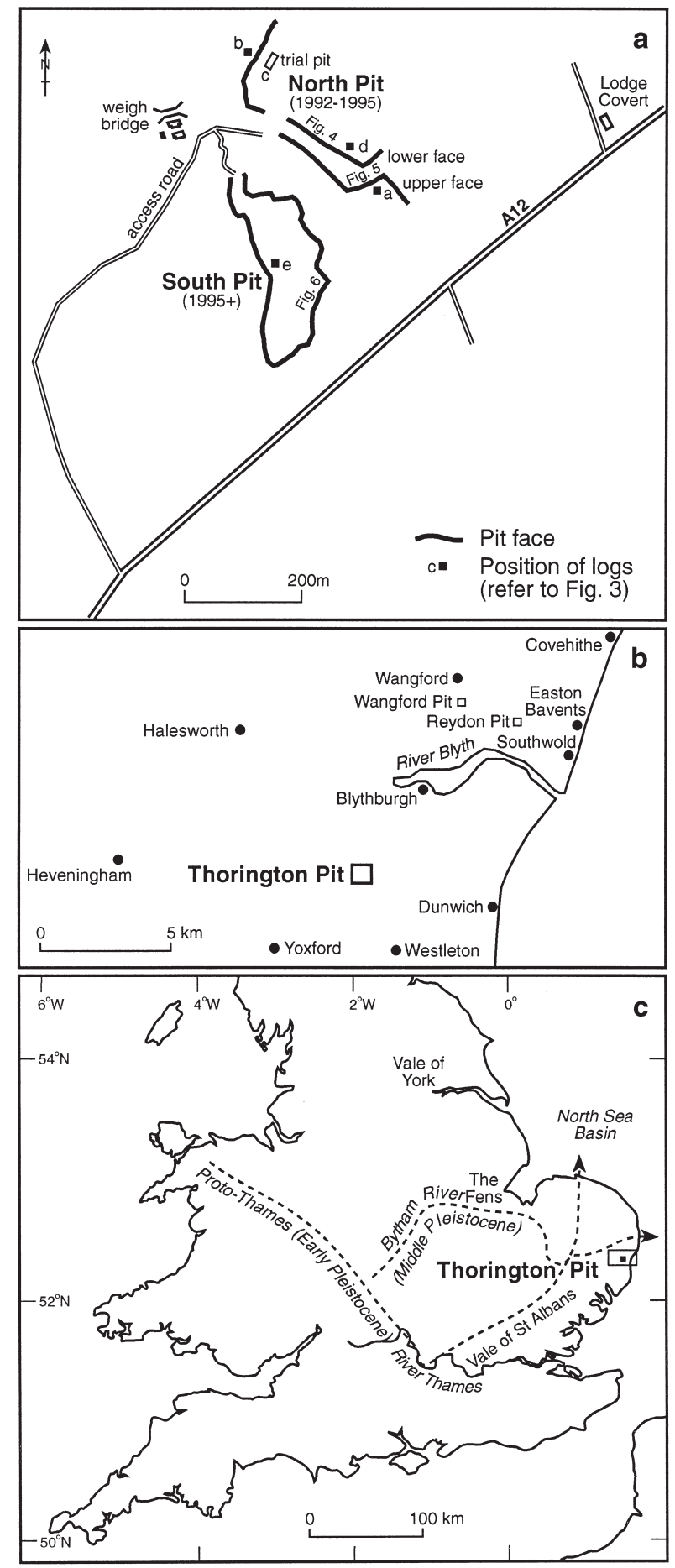

Figure 1. Location of the study area. (a) Location of sedimentary logs and diagrams included in Figures 3, 4, 5 and 6. (b) Location of Thorington Gravel Pit and sites referred to in the text. (c) The position of major drainage systems that affected East Anglia during the Early and Middle Pleistocene and locations referred to in the text.

shared a common provenance. Both units are characterized by pollen, foraminifera and mollusc assemblages that suggest cold stage conditions and falling sea level (Funnell \& West, 1962; Norton \& Beck, 1972, West \& Norton, 1974; West, 1961; West, Funnell \& Norton, 1980). Both Hey (1967) and West (1980) sug- gested that the deposits may have formed under the influence of glaciation, on the basis of exotic minerals introduced from Britain and/or Scandinavia, although this has been questioned in later studies (e.g. Zalasiewicz et al. 1991).

Hey (1982) concluded that the gravels of the Norwich Crag Formation may have been supplemented by material introduced by both the ancestral Thames and a precursor to the River Trent, whilst Burger (pers. comm. 1991) suggested that the exotic heavy-mineral component may have been derived from the Baltic River system. Sinclair (1990) proposed that northerly-derived flint pebbles and 'Rhaxella chert' from the Corallian of Yorkshire were transported into the Crag sands by longshore drift. Later, Hamblin et al. (1997) suggested that intervening estuaries would have prevented longshore transfer of material. They proposed that the Westleton Beds and intervening clay units, notably at Easton Bavents, Covehithe and Thorington, formed under the influence of the ancestral Trent Bytham River, flowing from the English Midlands. Hamblin et al. (1997) believe that the Bytham River ran through southern East Anglia parallel to the River Thames, in which the estuarine Chillesford Clay of the Norwich Crag Formation south of the study area was deposited.

The Westleton Beds occur as planar cross-stratified units, in sets up to $10 \mathrm{~m}$ thick, which dip southeast at $10^{\circ}$, as recognized by Hey (1967). He suggested that a modern analogue for these deposits is represented by the prograding beach-face deposits formerly exposed in excavations in the Dungeness beach plain (Hey, 1966). Subsequently, Mathers \& Zalasiewicz (1996) subdivided the Westleton Beds into three facies associations. The first, large-scale cross-stratified association represents a beach-face deposit. This association grades into a second, offshore, horizontally bedded sand association, which in turn is replaced in a seaward direction and is incised into by the products of high-energy, channellized rip-current deposits.

Apart from the impressions of marine shells reported by Spencer (1967), no lists of Quaternary fauna or flora occur in the literature for the Westleton Beds. Hamblin et al. (1997) reported Carboniferous, Jurassic, Late Cretaceous and Palaeogene palynomorphs from fine-grained clay beds from within the Westleton Beds exposed at the Thorington gravel quarry complex. Their samples yielded insufficient Quaternary pollen to indicate environment or age, although the authors suggest that the altitude and depositional environment of the Westleton Beds precludes deposition during the Antian/Bramertonian marine transgression, as previously suggested by Funnell, Norton \& West (1979). In common with Hey, Mathers \& Zalasiewicz (1988), they favour emplacement during the Baventian regression, but under the influence of the ancestral Trent Bytham River (Rose, 1994). 


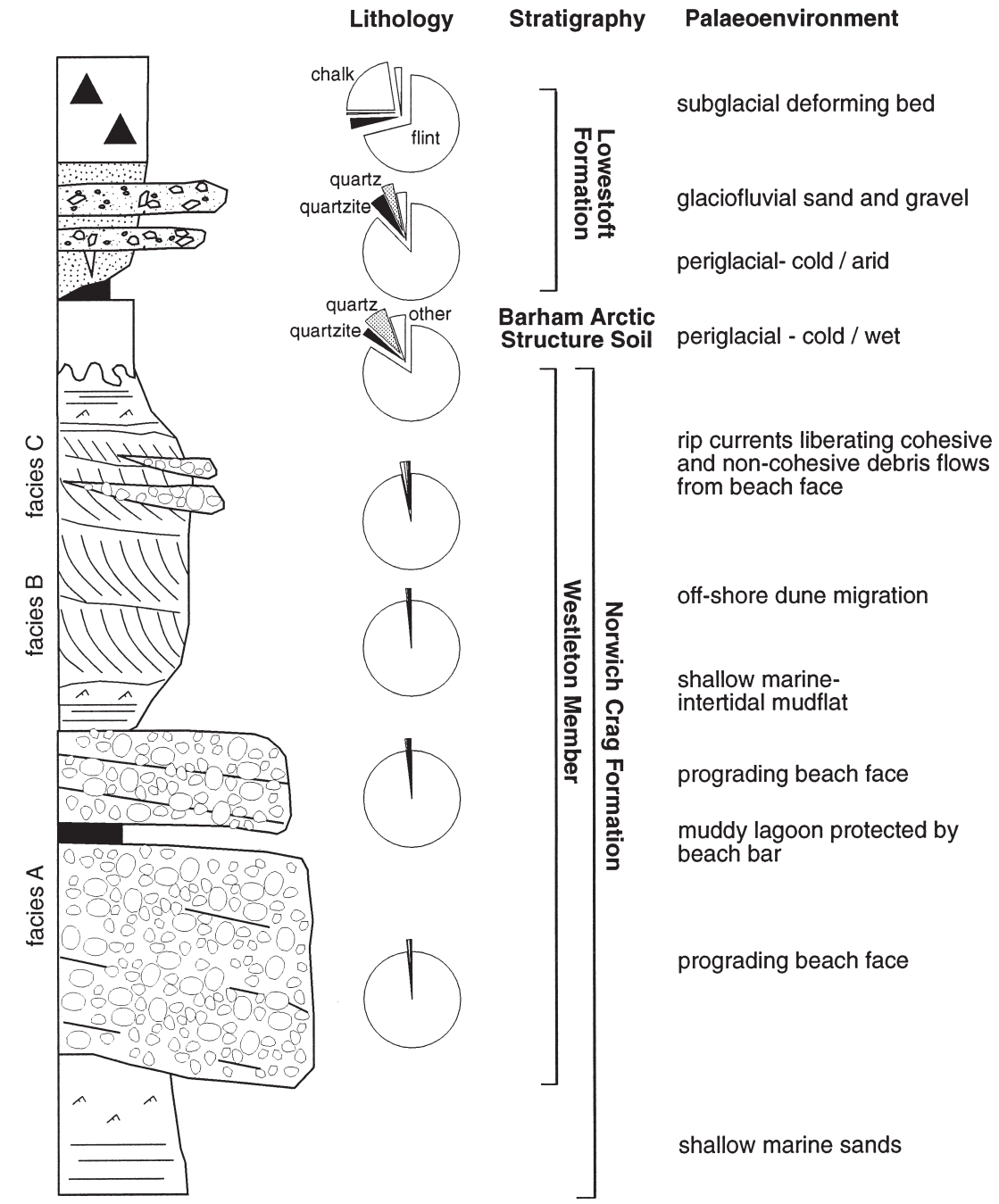

Figure 2. The inferred palaeoenvironments and stratigraphy of the sediments exposed in the Thorington gravel quarry complex, northern Suffolk.

\section{The Norwich Crag Formation at Thorington}

The lowest sections in the gravel quarry complex are dominated by units of the Norwich Crag Formation. The bulk of these deposits consist of gravels, sands and intervening finer-grained deposits of the Westleton Member. The sections in the member occur between $11 \mathrm{~m}$ and $18 \mathrm{~m}$ OD (Fig. 3), and present a detailed record of depositional environments associated with the unit.

\section{3.a. Sedimentology}

3.a.1. Unit 1

A trial pit in the north pit (TM 4227 7296; August 1994) revealed $2.85 \mathrm{~m}$ of fine- to medium-grained, dark-green to yellow sands (Fig. 3). The unit includes plane and wavy stratification and flaser bedding marked by silty-clay drapes within ripple-drift cross-stratification. Rare planar cross-stratified units indicate palaeocurrents towards $015-050^{\circ}$. The unit includes iron pans, poorly developed concretions, and worm-burrow fills, and is traversed by a system of high angle normal faults with throws of $1-4 \mathrm{~cm}$. These deposits comprise sands of the Norwich Crag Formation of Funnell \& West (1977), Mathers \& Zalasiewicz (1988) and Zalasiewicz et al. (1988).

\section{3.a.2. Unit 2}

Up to $4 \mathrm{~m}$ of well-rounded, flint-rich gravels overlie a channellized contact with the Norwich Crag Formation sands, at $8.2 \mathrm{~m} \mathrm{OD}$. The stratigraphical relationships, sedimentology and lithological composition of these gravels suggest that they form part of the Westleton Beds Member (Prestwich, 1871), which are widely reported to overlie directly the sands of the Norwich Crag in northeast Suffolk (Hey, 1967; Mathers \& Zalasiewicz, 1996). The vertebrate remains collected from these sediments are listed in Table 3, and the lithological composition is recorded in Table 2. At Thorington Pit, the Westleton Beds Member may be subdivided into an upper and lower unit on the basis of a marked change in bedding orientation (Figs 3,4). 


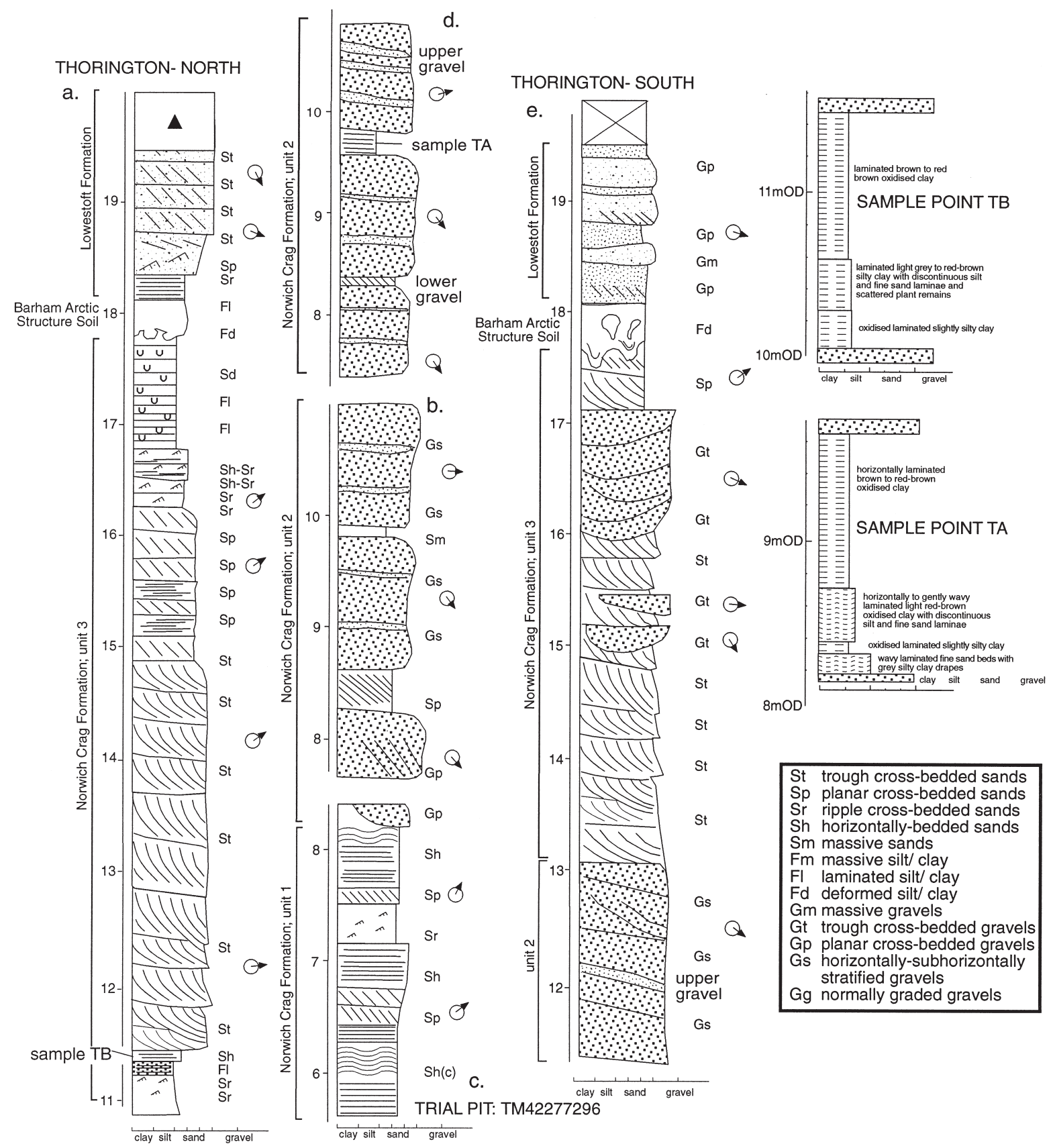

Figure 3. Composite facies logs for the south and north pits at Thorington.

The lower gravels of the unit consist of clast-supported, flint-dominated gravels with sand interbeds that form massive planar foresets $10-50 \mathrm{~cm}$ in thickness, inclined at $6-10^{\circ}$ towards $085-130^{\circ}$. Prominent reactivation surfaces mark subtle variations in dip angle and/or orientation throughout association $\mathrm{A}$ (Fig. 4). Gravel units are dominated by sub-rounded to well-rounded flint pebbles. These generally massive units exhibit crude imbrication, mostly down-dip, although locally up-slope. Normally-graded openwork lenses and planar cross-bedded units occur within the foresets of the association. The bedding is often characterized by textural variations and/or shape-sorting between beds and locally defined by thin
(5-25 cm), persistent beds or lenses of plane-stratified medium- to coarse-grained sand. Sand interbeds have conformable to gently concave lower contacts, and bedding is approximately normal to the dip of the gravel units, although a large interbed (Fig. 4) exhibits trough cross-beds, which indicates palaeocurrents toward $156-172^{\circ}$. Sand interbeds increase in number towards the northeast in the north pit, composing nearly $50 \%$ of the lower gravel unit.

The transition to the upper gravel is marked by a change in the orientation of forset units towards 060 $095^{\circ}$. The upper gravel body has a wavy, erosive contact with the lower gravel in the northern section of the north pit, marked locally by the occurrence of a coarse 
Table 1. The British Quaternary stratigraphic nomenclature and equivalent stages in the Netherlands

\begin{tabular}{|c|c|c|}
\hline $\begin{array}{l}\text { Marine oxygen } \\
\text { isotope stages }\end{array}$ & British Isles & Netherlands \\
\hline 1 & Flandrian & Holocene \\
\hline $2-5 d$ & Devensian & Weichselian \\
\hline $5 \mathrm{e}$ & \multirow[t]{2}{*}{ Ipswichian } & Eemian \\
\hline 6 & & Waarthe \\
\hline 7 & \multirow[t]{3}{*}{ Wolstonian/Ilfordian } & Saale/Drenthe \\
\hline 8 & & Drenthe \\
\hline 9 & & Domnitz \\
\hline 10 & \multirow[t]{2}{*}{ Hoxnian } & Fuhne \\
\hline 11 & & Holsteinian \\
\hline 12 & \multirow[t]{2}{*}{ Anglian } & Elster \\
\hline 13 & & \\
\hline 14 & \multirow[t]{16}{*}{ Cromerian } & \\
\hline 15 & & Cromerian IV \\
\hline & & Nordbergum \\
\hline 16 & & Glacial C \\
\hline \multirow[t]{2}{*}{17} & & Interglacial III \\
\hline & & Rosmalen \\
\hline 18 & & Glacial B \\
\hline \multirow[t]{2}{*}{19} & & Westerhoven \\
\hline & & Interglacial II \\
\hline 20 & & Glacial A \\
\hline \multirow[t]{2}{*}{21} & & Waardenburg \\
\hline & & Interglacial I \\
\hline \multirow[t]{6}{*}{22} & & Bavelian \\
\hline & & Menapian \\
\hline & & Waalian \\
\hline & & Eburonian \\
\hline & Beestonian & \\
\hline & Pastonian & \\
\hline \multirow[t]{6}{*}{$64 ?$} & Pre-Pastonian/ & $\mathrm{C} \%$ \\
\hline & Baventian & $\mathrm{C} 4 \mathrm{c}$ \\
\hline & Bramertonian/ & Tiglian \\
\hline & Antian & C3 \\
\hline & Thurnian & $\mathrm{B}$ \\
\hline & Ludhamian & A \\
\hline 103 & Pre-Ludhamian & Praetiglian \\
\hline 104 & Pliocene & Pliocene \\
\hline
\end{tabular}

gravel lag overlain by a plane-stratified silty sand unit (Fig. 4). Elsewhere, the contact is marked by a lenticular bed of laminated grey to brown silty clay, up to $70 \mathrm{~cm}$ thick, occurring at 9.3-9.6 m OD. Samples for pollen analysis (see below) were collected at sample point TA (Fig. 3). Elsewhere the contact between the two gravel bodies is less distinct and apparently gradational. However, the upper gravels contain rare,
Table 3. Vertebrate finds at Thorington

$\begin{array}{ll}\text { Proboscideans } & \\ \quad \begin{array}{l}\text { Anancus arvernensis } \\ \text { Archidiskodon meridionalis }\end{array} & \text { gomphothere mastodont } \\ \text { Perissodactyls } & \text { elephant } \\ \quad \text { Equus stenonis } & \text { horse } \\ \begin{array}{l}\text { Artiodactyls } \\ \quad \text { Eucladoceros sedgwicki } \\ \text { Gazella anglica }\end{array} & \text { deer } \\ \text { Cetacea } & \text { gazelle } \\ \text { Whale } & \\ \text { Delphinus delphis } & \text { species unidentified } \\ \end{array}$

Collected by Mr R. Mutch at the basal lag gravels of the Westleton Beds Member (unit 2) of the Norwich Crag Formation sands, Thorington

relatively thin $(2-10 \mathrm{~cm})$ sand beds within subrounded to well-rounded flint gravels, which exhibit large-scale cross-stratification towards $070-100^{\circ}$ at $8-12^{\circ}$. Both up- and down-dip imbrication is evident within the gravel units.

\section{3.a.3. Unit 3}

At $10.9 \mathrm{~m}$ OD, a planar erosional contact marks a transition into two units composed of fining-upward sequences of fine sand and laminated silt and clay beds, which are separated by up to $6 \mathrm{~m}$ of orange to pale yellow medium- to coarse-grained cross-bedded sand (Fig. 3).

Sections in the north pit in 1994-5 exposed largescale, tangentially-based tabular, trough, and festoon cross-bedding (facies Sp, St). Sets vary in thickness from $30 \mathrm{~cm}$ to $70 \mathrm{~cm}$. Gravels occur as lenticular beds, and also occur as thin, laterally impersistent pebbly lags between sets (at first and second order bounding surfaces), and within sets (reactivation surfaces and slipfaces of individual cross-sets). Three major bounding surfaces are prominent, dipping at $1-3^{\circ}$ towards $352-025^{\circ}$, and palaeocurrents measured from trough axes and planar cross-beds indicate flow directions towards $040-100^{\circ}$ (Fig. 5). In the south pit, the upper part of the unit includes isolated lenticular beds, and stacked units of channellized, sub-rounded to well-

Table 2. Lithological composition ( $8-16 \mathrm{~mm}$ fraction) of sediments exposed at Thorington

\begin{tabular}{|c|c|c|c|c|c|c|c|c|c|c|c|c|c|c|}
\hline & 1 & 2 & 3 & 4 & 5 & 6 & 7 & 8 & 9 & 10 & 11 & 12 & 13 & 14 \\
\hline Flint & 97.9 & 98.5 & 98.5 & 98.3 & 98.0 & 98.2 & 96.7 & 96.4 & 96.8 & 84.2 & 87.6 & 88.2 & 71.2 & 93.0 \\
\hline Quartz & 0.4 & 0.5 & 0.3 & 0.6 & 0.6 & 0.3 & 1.3 & 1.8 & 1.1 & 2.6 & 3.0 & 6.7 & 3.2 & 1.4 \\
\hline Quartzite & 0.8 & 0.5 & 0.3 & 0.6 & 0.3 & 0.6 & 1.0 & 0.8 & 0.7 & 7.9 & 4.5 & 3.5 & 0.7 & 1.4 \\
\hline Chert & 0.0 & 0.0 & 0.0 & 0.0 & 0.0 & 0.0 & 0.3 & 0.4 & 0.7 & 1.9 & 1.8 & 0.4 & 0.4 & 1.0 \\
\hline Sandstone & 0.0 & 0.2 & 0.3 & 0.3 & 0.3 & 0.3 & 0.0 & 0.0 & 0.0 & 2.6 & 1.5 & 0.0 & 0.7 & 1.0 \\
\hline Limestone & 0.4 & 0.0 & 0.0 & 0.0 & 0.3 & 0.0 & 0.0 & 0.0 & 0.0 & 0.0 & 0.9 & 0.0 & 0.4 & 0.5 \\
\hline Chalk & 0.0 & 0.0 & 0.0 & 0.0 & 0.0 & 0.0 & 0.0 & 0.0 & 0.0 & 0.0 & 0.0 & 0.0 & 22.5 & 0.0 \\
\hline Ironstone & 0.0 & 0.0 & 0.3 & 0.0 & 0.3 & 0.3 & 0.7 & 0.3 & 0.4 & 0.0 & 0.0 & 0.0 & 0.0 & 0.0 \\
\hline Ign/meta & 0.0 & 0.0 & 0.0 & 0.0 & 0.0 & 0.0 & 0.0 & 0.0 & 0.0 & 0.4 & 0.0 & 0.8 & 0.7 & 1.0 \\
\hline Other & 0.4 & 0.2 & 0.5 & 0.3 & 0.3 & 0.3 & 0.0 & 0.3 & 0.4 & 0.4 & 0.6 & 0.4 & 0.4 & 0.7 \\
\hline No. & 238 & 407 & 399 & 347 & 352 & 327 & 304 & 367 & 277 & 266 & 330 & 254 & 285 & 415 \\
\hline
\end{tabular}

1-2, Westleton Member, unit 2, association A; 3-4, unit 2, association B; 5-6, Westleton Member, unit 3 (pebbly sands); 7-8, unit 3 (channelized gravels); 9, gravels within Barham Arctic Structure Soil; 10-12, Lowestoft Formation gravels; 13, Lowestoft Formation, unweathered diamicton; 14, Lowestoft Formation, weathered diamicton. 


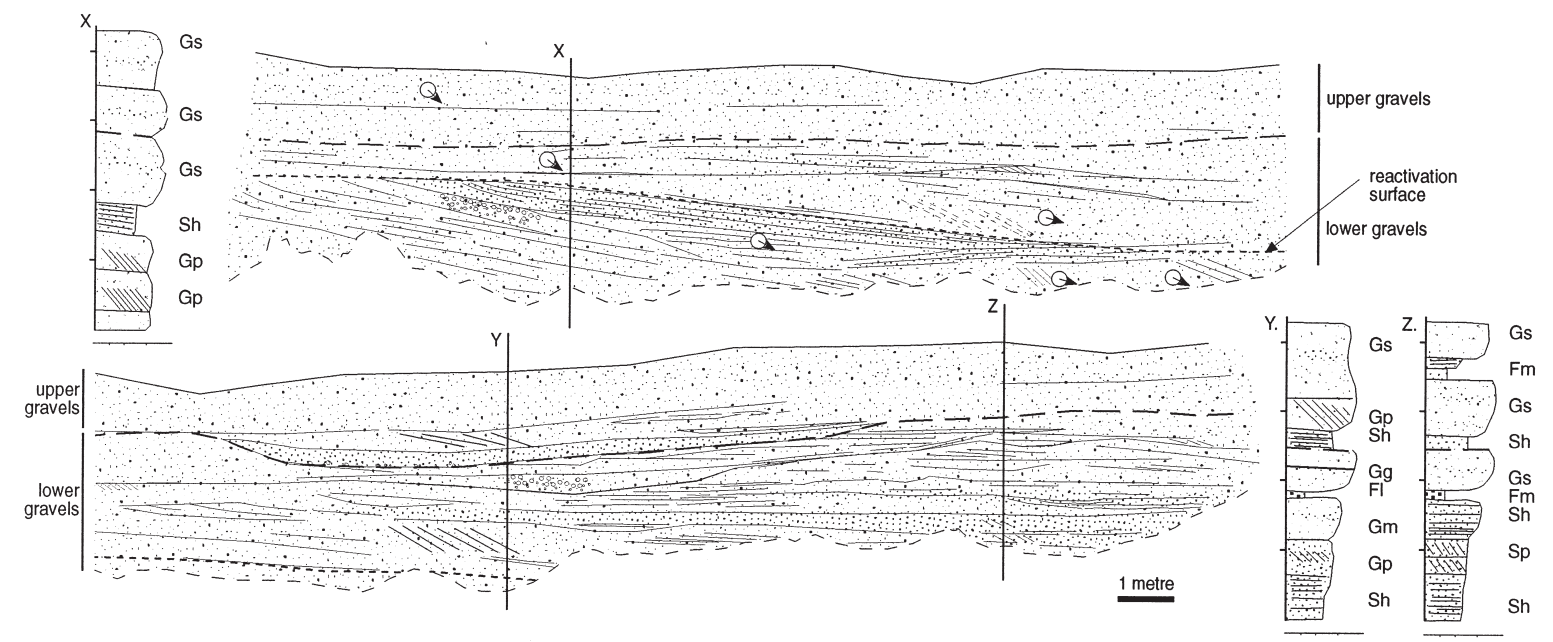

Figure 4. Detail and facies logs of unit 2 of the Westleton Member, north pit, Autumn 1994 (for abbreviations see key in Fig. 3).

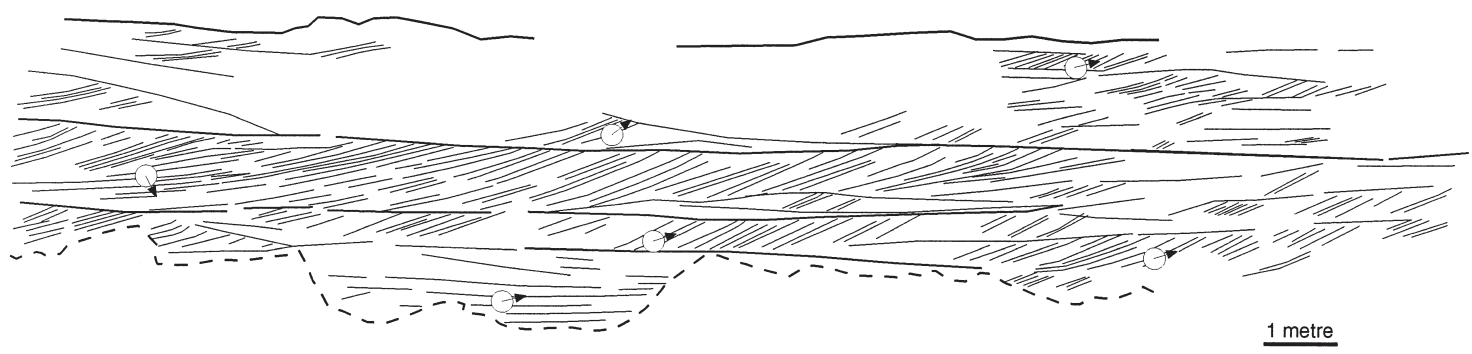

Figure 5. Detail of unit 3 of the Westleton Member, large-scale, subaqueous sandy bedforms exposed in the north pit, Autumn 1994.

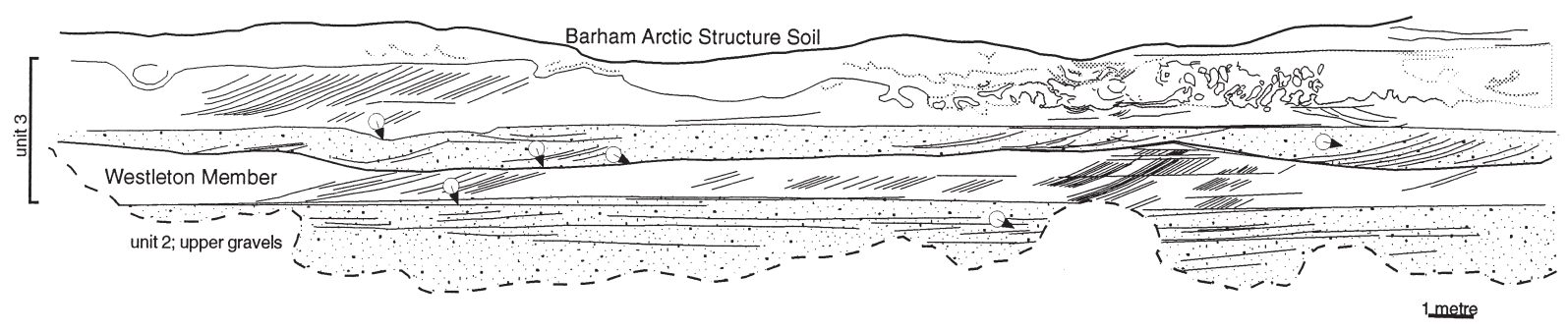

Figure 6. Detail of units 2 and 3 of the Westleton Member and the Barham Arctic Structure Soil, south pit, Spring 1997.

rounded flint-rich gravels (Fig. 6), in beds up to $50 \mathrm{~cm}$ in thickness, comprising fining-upward sequences of massive, trough cross-bedded, and normal- and inversegraded gravels. The stacked units have a wavy, channellized base and have a lateral extent of $25 \mathrm{~m}$ through the section. The channellized gravel units are overlain by up to $2.5 \mathrm{~m}$ of tabular and trough cross-bedded sand sets $30-60 \mathrm{~cm}$ in thickness. The lithological composition and shape characteristics of gravel samples from this unit is similar to those of the gravels of unit 2 (Table 3).

The lower fine unit consists of horizontally bedded fine- to medium-grained sand and wavy to ripple cross-bedded fine- to medium-grained sand. Form sets within the rippled sand exhibit marked symmetry (ripple indices: 5-7.5; ripple symmetry indices: 1.09-1.33), and opposed cross-bedding, chevron and bundled upbuilding is evident. Locally, the ripple cross-bedded sand passes upward into horizontally laminated silt and clay units with laterally impersistent, fine-sand laminae. This bed was originally observed and sampled for palaeomagnetic analysis by B. M. Funnell and D. Hallam in 1993. Samples for palaeobotanical analysis were collected from point TB, as shown in Figures 3 and $7 \mathrm{a}$. The results are presented below.

The upper fine unit forms a fining-upwards sequence from horizontally bedded medium-grained sands to finer units containing wavy and symmetrical to asymmetrical ripple cross-bedding, and apparently massive silty sand and silt units, or laminated silt and clay beds. Mud drapes within foreset beds, flaser and convolute bedding are present in the upper fine unit. In the north pit, the laminated silt and clay unit is up to $100 \mathrm{~cm}$ in thickness, although its upper portions are 


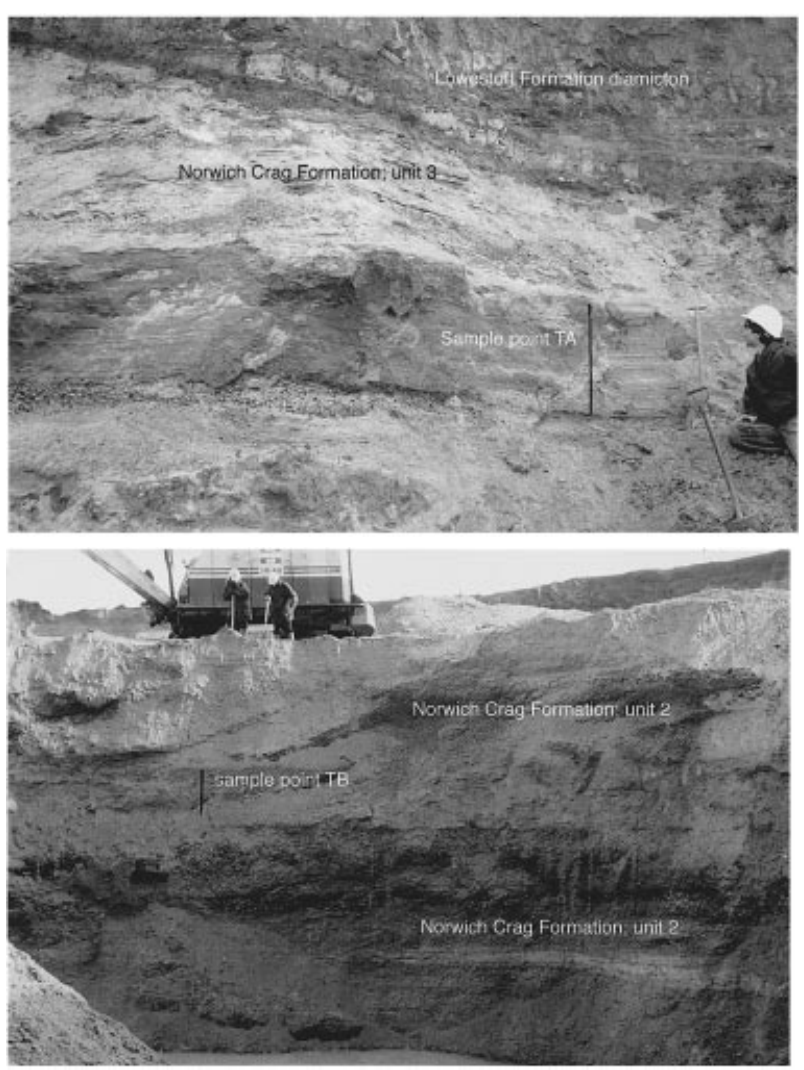

Figure 7. (a) Sample point TA, Thorington gravel quarry complex. (b) Sample point TB, Thorington gravel quarry complex.

often truncated by the Barham Arctic Structure Soil. In the south pit, the upper laminated silt and clay unit is up to $1.6 \mathrm{~m}$ thick, and is erosively overlain by coarse-grained glaciofluvial gravels of the Lowestoft Formation. Locally, clay beds contain cracks and tapered veins that are infilled with fine sand. The clay units between these veins form lenticular units that are concave upwards.

\section{3.b. Palaeobotany}

\section{3.b.1. Palynology}

Samples for pollen analysis were collected from profiles TA and TB in the fine sediments of unit 2 described above(Figs 3, 7a, 7b). They were prepared using standard chemical methods (West, 1977), and modified using sodium pyrophosphate (Bates, Coxon \& Gibbard, 1978). Pollen type nomenclature follows Andrew (1970), together with some types listed in Birks (1973). The pollen diagram from profile TB (Fig. 8) and counts from site TA (Table 4) have been calculated on the basis of percentages of total land pollen and spores, excluding aquatic taxa. The latter, together with pre-Pleistocene taxa, are calculated as a percentage of total palynomorphs.

Figure 8. Pollen diagram from sample TB, Thorington gravel quarry complex.

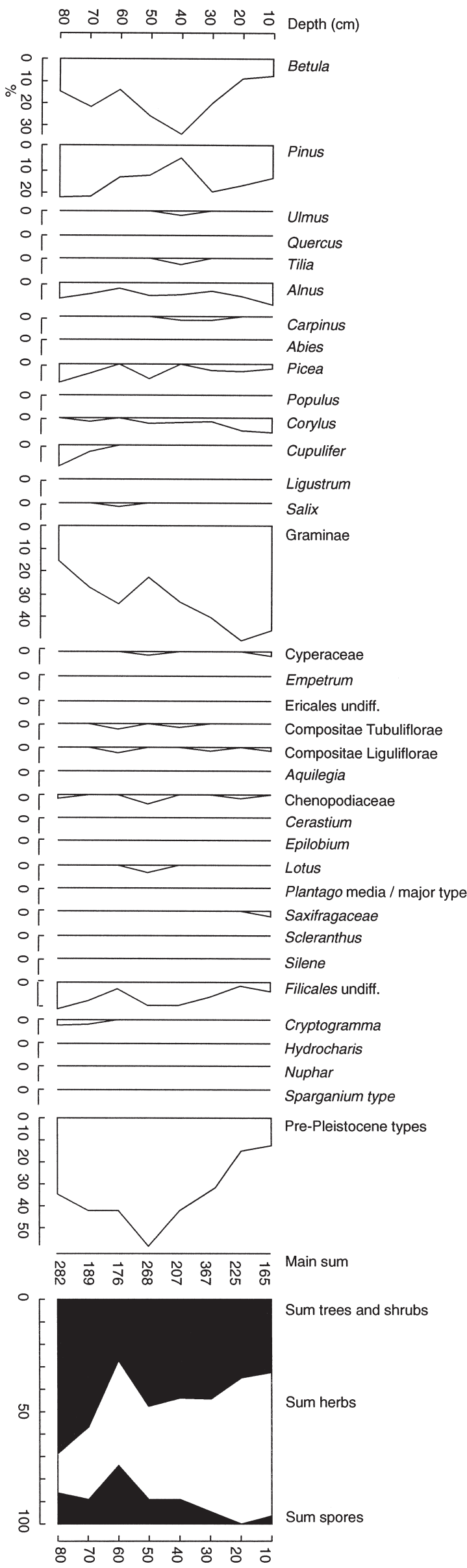


Table 4. Pollen analysis from samples TB and TC

\begin{tabular}{|c|c|c|c|c|c|}
\hline$\%$ & B: $30 \mathrm{~cm}$ & B: $40 \mathrm{~cm}$ & B: $50 \mathrm{~cm}$ & $\mathrm{C}: 15 \mathrm{~cm}$ & $\mathrm{C}: 20 \mathrm{~cm}$ \\
\hline Betula & 8.3 & 10.6 & 11.9 & 7.4 & \\
\hline Pinus & 27.2 & 34.4 & 47.7 & 77.8 & 70.0 \\
\hline Alnus & 5.8 & 3.3 & 4.6 & & \\
\hline Carpinus & 0.8 & & & & \\
\hline Ostrya & & & 2.0 & & \\
\hline Picea & 6.6 & 5.3 & 4.6 & & \\
\hline Corylus & 3.3 & 1.8 & & & \\
\hline Salix & & 0.7 & & & \\
\hline Cupulifer & 2.5 & 9.9 & 8.3 & 3.7 & \\
\hline Gramineae & 31.4 & 24.5 & 9.2 & 7.4 & 30.0 \\
\hline Comp. Lig. & 2.5 & 3.7 & & & \\
\hline Comp. Tub. & 0.8 & & & & \\
\hline Chenopodiaceae & 2.5 & 1.3 & & & \\
\hline Scleranthus & & 0.7 & 1.8 & & \\
\hline Filicales & 1.7 & 3.3 & 0.9 & & \\
\hline Cryptogramma & 6.6 & 4.0 & 9.2 & & \\
\hline Azolla & & & 0.7 & & \\
\hline Lemna & & & & 3.2 & \\
\hline Pediastrum & & & & 3 & 9.1 \\
\hline Reworked types & 26.6 & 30.7 & 35.1 & 9.7 & \\
\hline Main sum & 121 & 151 & 109 & 27 & 10 \\
\hline Sum trees and shrubs & 54.5 & 66.2 & 78.9 & 88.9 & 70.0 \\
\hline Sum herbs & 37.2 & 26.5 & 11.0 & 11.1 & 30.0 \\
\hline Sum spores & 8.3 & 7.3 & 10.1 & & \\
\hline
\end{tabular}

The pollen spectra from sample TA and TB, although from different locations in the transition from sediments of unit 2 to unit 3 , are generally well preserved and very similar. They will therefore be discussed together and minor differences noted. The spectra can be grouped into a single GramineaeBetula-Pinus pollen assemblage biozone (pab). Despite substantial changes in the frequency of certain taxa, tree pollen consistently represents $40-79 \%$ of the total land pollen. All levels in the diagram from TB (Fig. 8) are dominated by Gramineae pollen, but the counts for site TA (Table 4) show lower, although still significant, frequencies. These high grass frequencies are accompanied by few herb pollen taxa characteristic of dry, partially-disturbed grassland, including Plantago major/media type, Compositae (Liguliflorae), Scleranthus, Lotus and Cerastium. The pollen of marsh and aquatic vegetation, associated with the pond itself, include Nuphar, Hydrocharis, Azolla and Sparganium type. The high frequencies of reworked pre-Pleistocene palynomorphs found throughout emphasize the volume of freshly eroded material entering the water-body (cf. Riding et al. 1997). The upward decrease in this inwash indicates infill of the basin and colonization of newly emergent surfaces by plants, particularly Gramineae.

Tree pollen are dominated by Pinus, but Betula is also important, whilst Alnus is the only other tree pollen present in numbers that suggest local growth of this tree. The abundance of Filicales spores may be associated with alder carr in this situation. Pollen of Carpinus, Quercus, Ulmus and Fraxinus, to judge from their low numbers, either represent trees growing distant from the site or are reworked.
Minor variations in the diversity of the assemblages, and particularly the content of Pinus, may reflect differences in water depth or distance from the basin margins, but most likely are due to minor changes in current and sediment transport. In this context it is important to consider the taphonomy of the pollen assemblage. The large proportion of pre-Pleistocene material, mainly inwashed from a westerly direction by stream transport (Riding et al. 1997), may indicate a similar derivation for some of the Pleistocene taxa. However, their better preservation and the ecological consistency of the assemblage makes this unlikely.

The Chenopodiaceae in both samples suggests proximity to coastal saltmarsh. However, overall the assemblages recorded from both TA and TB are typical of a freshwater pond, or a small lake with local fringing vegetation of marsh and aquatic plants into which material was being washed, possibly from a stream or river. By contrast coniferous woodland dominated the drier areas, with an understorey of ericaceous shrubs and Cryptogramma, suggesting acid soils locally. The change in the spectra through the sequence is slight and may indicate local seral, rather than climatic, change.

The lack of substantial compositional change in the spectra prevent confident correlation with events known from elsewhere. The highly restricted assemblage in both beds is typical of that recovered from cool to cold stage events in the Early Pleistocene marine sequences in East Anglia. Here assemblages dominated by Pinus, accompanied by substantial quantities of Gramineae and often also accompanied by Ericales, are very common (West, 1980). However, the occurrence of Picea, Alnus and Corylus, together 
with very low numbers of mixed oak forest genera (e.g. Ulmus, Quercus, Tilia and Carpinus) suggest conditions were not as severe as during the early part of the Baventian/?pre-Pastonian 'a' Stage, where assemblages contained far lower diversities (Zalasiewicz et al. 1991). The assemblage possibly represents conditions intermediate between those of the extreme cold typified by that of the Baventian (that occurs in sediments that stratigraphically underlie these sediments) and full interglacial conditions (cf. West, 1980), that is, they could represent an interstadial-type event in which boreal-like forest flourished in the hinterland, but with grassland-dominated communities on the coastal sand areas adjacent to the locality.

The spectra are consistent with, but not directly indicative of, a pre-Pastonian ' $a$ ' age to which the Westleton Member is generally assigned.

\section{3.b.2. Plant macrofossils}

A sample was collected from the $20-35 \mathrm{~cm}$ level at site TA for plant macrofossil analysis. In the laboratory the whole sample was taken and disaggregated in cold water. It was then washed through a nest of sieves down to $150 \mu \mathrm{m}$ mesh size. Macroscopic plant remains were then picked from the residue and identified. The nomenclature follows Flora Europaea (1964-93). The results are given in Table 5.

The assemblage recovered is of limited diversity, but was well preserved. It predominantly comprises plants of open dry grassland including Plantago cf. media and Polygonum lapathifolium, while Scleranthus cf. annuus indicates local sandy and gravelly surfaces. A second group of plants are those of open ground, pond margins and ditches, and include Bidens tripartita, Eleocharis palustris/uniglumis, while the Juncus seeds also originated from parent plants growing in local marsh. The salt-marsh plant Chenopodium bitryoides/rubrum indicates salt water in the vicinity. Submerged plants are represented by the aquatic alga Chara. Finally, the single find of an Alnus fruit confirms the pollen evidence for local stands of this tree.

The plant macrofossils indicate that the sediments were deposited in a standing water environment. The over-representation of waterside, damp ground and aquatic taxa suggest that the assemblages are dominated by material from in or immediately around the water body. For this reason it is difficult to comment on the regional environment, although the plant macrofossil assemblage indicates temperate conditions; many of the plants are still growing in Suffolk today, with the exception of Picea and Cupulifera. Indeed the plant macrofossil assemblage complements the interpretations derived from the pollen assemblages presented above, that the vegetation is typical of a cool environment undergoing climatic amelioration, with small plants reacting more quickly to the ongoing temperature changes.
Table 5. Plant macrofossils from site TA level $35 \mathrm{~cm}$ in Thorington

\begin{tabular}{|c|c|c|}
\hline \multicolumn{3}{|l|}{ Trees } \\
\hline Alnus sp. & fruit & 1 \\
\hline \multicolumn{3}{|l|}{ Herbs } \\
\hline Plantago cf. media & seed & 1 \\
\hline Sclenanthus cf. annuus & fruit & 1 \\
\hline Polygonum lapathifolium & nut & 1 \\
\hline Bidens tripartita & achene & 3 \\
\hline Bidens sp. & barbed awns & 14 \\
\hline Eleocharis palustris/uniglumis & nut & 1 \\
\hline \multicolumn{3}{|l|}{ Herbs/Shrubs } \\
\hline Chenopodium botryoides/rubrum & seed & 1 \\
\hline \multicolumn{3}{|l|}{ Aquatic } \\
\hline Characae & oospores & 11 \\
\hline \multicolumn{3}{|l|}{ Unclassified } \\
\hline cf. Eleocharis sp. & nut & 1 \\
\hline Juncus sp. & seed & 1 \\
\hline Ranunculus sp. & achene & 1 \\
\hline \multicolumn{3}{|l|}{ Miscellaneous } \\
\hline Beetle & wing case & 1 \\
\hline Foraminiferid & & 1 \\
\hline Fungae & sclerotia & 1 \\
\hline Leaf & margin & 1 \\
\hline Moss & stem with leaves & 1 \\
\hline Woody fragments & (unidentified) & 10 \\
\hline Total weight of sample & $200 \mathrm{~g}$ & \\
\hline Volume & $115 \mathrm{~cm}^{3}$ & \\
\hline
\end{tabular}

\section{3.c. Vertebrate remains and palaeomagnetic analyses}

The vertebrate remains recovered from the sands and gravels of unit 2 in the Thorington gravel quarry complex between 1991 and 1995 are shown in Table 3. The vertebrate fauna is similar to that recorded from the Norwich Crag Formation deposits elsewhere (Spencer, 1971). Of principal palaeoenvironmental significance is the occurrence of whale and dolphin remains. While dolphin remains have not been recorded elsewhere, whale vertebrae have been recovered from the Norwich Crag Formation in cliff sections at Southwold and Walberswick, and also from former gravel pits at Holton (Spencer, 1971).

The lower fine unit of unit 3 , which was sampled for pollen analysis (sample TA), was deposited during an episode of normal magnetic polarity (D. Hallam, unpub. Ph.D. thesis, Univ. East Anglia, 1995), consistent with the Late Baventian/pre-Pastonian 'a' age suggested on other criteria.

\section{Discussion: depositional environments and stratigraphical significance}

The markedly rounded shape of the gravel clasts and the sedimentary structure of unit 2 suggests that the gravels are the product of a prograding beach face, with modern analogues at Dungeness, Orfordness, Sizewell and Chesil Beach (Hey, 1967; Carr, 1971; Hart \& Plint, 1989; Mathers \& Zalasiewicz, 1996). These gravels accumulated at the margins of the Early Pleistocene Crag Sea. The elevation of these gravels 
with respect to modern sea level may be a function of local tectonics. The southern North Sea Basin has undergone active subsidence throughout the Quaternary period, and areas marginal to this subsidence have been uplifted due to the progressive eastward downtilting of the British landmass on the opening of the Atlantic Ocean (Taylor \& Smalley, 1969; Clarke, 1973; Mathers \& Zalasiewicz, 1988).

As at Wangford (Westleton Beds facies A of Mathers \& Zalasiewicz, 1996), the gravels of the Westleton Member can be subdivided into an upper, more steeply dipping subfacies, and a lower, shallowdipping subfacies. However, the variations in foresetdip direction that occur within the gravels of the Westelton Member at Thorington are likely to be the result of a change in the dominant direction of progradation, rather than relative height within the beach profile, as the generally low dip values suggest that the subfacies were deposited at a similar level in the prograding beach face. Reactivation surfaces within the upper gravel unit probably resulted from less marked change in the angle and direction of beach progradation. There is vertical variation in shape-sorting between adjacent foreset beds, with some facies dominated by 'rods' and 'blades', while other facies are largely composed of 'spheres'. This shape-sorting has been reported from typical beach- and shore-face conglomerates by Bluck (1969) and Dobkins \& Folk (1970), and is likely to have promoted the 'up-dip' imbrication noted in some beds. However, gravel foreset beds also exhibit localized cross-bedding. It is possible that both 'up-dip' imbrication and cross-bedding may have occurred in association with localized eddies in storm conditions.

The lenticular bed of grey to brown silty clay, which occurs at the contact between the upper and lower gravels of unit 2, probably accumulated in a body of standing water, protected by surrounding gravel bars high on the beach face, i.e. a lagoon. The palaeobotany of sample TB supports these conclusions, and suggests that the body of water was fed by a low discharge stream, which, on the basis of inwashed palynomorphs (Riding et al. 1997), appears to have flowed from a westerly direction. The intercalated sand lenses that occur through the lower and upper parts of the unit may have been blown into the body of water by periodic, high-velocity onshore winds, or may have been brought in by wave activity during storm events. The bed appears to mark an interlude and a cessation of shingle supply during the development of the beach before progradation was reinitiated, in a more northerly direction.

Unit 3 comprises a lower fine-grained unit (facies $\mathrm{Sr}$, Sh Fl; sample TA) overlain by large-scale crossbedded sand (facies $\mathrm{Sp}, \mathrm{St}$ ), which is in turn overlain by a further fine-grained unit (facies Sh, Sr, Fl, Sd). Bounding surfaces, reactivation and variations within the finer units at the base and top of unit 3 attest to a fluctuating water level throughout the deposition of the unit.

Both the upper and lower fine units that bound the cross-bedded sand facies exhibit sedimentary structures typical of shallow marine, wave-dominated or intertidal environments. The sand-filled veins that truncate the clay laminae in the upper fine unit are thought to represent desiccation cracks. Similar features have been reported from laminated clays exposed at Easton Bavents and Covehithe (Hamblin et al. 1997). The palynology of sample TA is again consistent with the input of freshwater into a coastal environment by a river flowing from the west.

The large-scale cross-bedded sands of unit 3 are interpreted here to equate to the Westleton Beds facies B of Mathers \& Zalasiewicz (1996), who regarded the planar cross-stratification as the product of wave/storm processes and small-scale cross-sets as indicating offshore transport through the migration of small dunes. While the two-dimensional bedforms are similar to that reported from Quay Lane Pit, Reydon (TM 483 775; Mathers \& Zalasiewicz, 1996), the scale of the trough cross-stratification in the northern section at Thorington suggests that offshore dune migration was of greater magnitude than reported elsewhere. The isolated and stacked units of channellized, well-rounded, flinty gravels exposed in the south pit at Thorington probably represent Westleton Beds facies C of Mathers \& Zalasiewicz (1996), which they regarded as products of high-velocity, nearshore ripcurrents. Massive, normal- and inverse-graded gravel units document both cohesive and non-cohesive/turbulent debris flows from the shore face, which probably occurred during storm events.

In summary, units 2 and 3 record fluctuating, but transgressing, sea level throughout the deposition of the Westleton Beds Member. Palaeoecological and palaeomagnetic evidence suggests that beach progradation, lagoonal, estuarine and off-shore deposition took place under a cool to cold climate, probably during amelioration at the end of the Baventian/prePastonian 'a' Stage. This stage is equated with the Tiglian C4c Substage in the Netherlands sequence (Gibbard et al. 1991). The lithological composition of the clast component of both beach gravels and ripcurrent deposits suggests that both the River Thames and the Bytham River may have provided gravel to the margins of the Crag Sea. On the basis of the lithological compositions recorded in Table 3, it is impossible to suggest which river dominated the gravel supply. The gravel component of the Westleton Beds Member is dominated by flint, and both the Bytham River and River Thames are likely to have excavated Palaeogene outcrops to the west and southwest. Previous inferences regarding the derivation of the gravels has largely relied on the more exotic components within the gravels. This is problematic because of the fact that most shingle beaches have a polycyclic origin; one can- 
not discount the role of longshore drift in the provision of distinctive 'spicular flints' and other lithologies that may have source areas in Lincolnshire and Yorkshire (Sinclair, 1990).

Although it is practically impossible to determine the morphology of the coast and nature of sedimentary cells that operated in the Crag Sea at this time, the rip-current deposits and the gravelly lags within large, sandy bedforms, which occur in the sequence directly above the prograding beach deposits, bear testament to a high-energy coastal environment capable of the longshore transport of large amounts of shingle both from the beach face and off-shore. It is unlikely that the estuaries that developed at the margins of the Crag Sea would have curtailed these littoral movements, as suggested by Hamblin et al. (1997). In addition, much of the gravel that constitutes the Westleton Beds is likely to have been deposited in the off-shore zone during earlier cold stages. Therefore, while the heavy mineralogy and reworked palynomorphs present within the clay beds that are associated with the Westleton Member have been used to determine whether the River Thames or Bytham River was responsible for their deposition, the provenance of the clast component of the Westleton Beds Member is likely to be more complex.

\section{Conclusions}

The extensive exposure of the Westleton Member at Thorington provides considerable support for previous evidence that it was deposited at a gravelly shoreline (Hey, 1967; Mathers \& Zalasiewicz, 1996). All three successive facies described by Mathers \& Zalasiewicz (1996) have been exposed in the quarry complex between 1994 and 1997.

The palaeobotany of fine beds that occur within the Westleton Beds Member is consistent with emplacement during a cold stage, although many elements of the plant macro- and micro-fossil assemblage suggest climatic amelioration, perhaps either at the beginning or at the end of a cold stage or during an interstadial. The stratigraphical, palaeoecological and palaeomagnetic evidence presented here suggests that the Westleton Beds are of Baventian/pre-Pastonian 'a' age (Tiglian C4c Substage). The fine beds that occur between two distinct progradational phases in the beach-face deposits appear to have accumulated during a phase of climatic amelioration that might have resulted in sea-level stability and an hiatus in gravel deposition within an episode of generally stable low sea level and abundant sediment supply. The deposition of two further fine beds in intertidal, estuarine environments suggest a fluctuating sea level throughout the phase of marine transgression that was responsible for the deposition of the Westleton Member.

Acknowledgements. The authors thank Professor B. M. Funnell and Dr D. Hallam for assistance and drawing our attention to this site; Mr R. Mutch for discussion and providing a list of faunal remains recovered from the Westleton Beds Member; Dr A. Davis for assistance in the field; $\mathrm{Mr}$ P. Lonergan and Mr M. Perry for permitting access to the site; Dr J Vandenberghe for helpful comments on an earlier draft of this paper and Dr J. Zalasiewicz for generous advice at all stages of this work.

\section{References}

Andrew, R. 1970. The Cambridge pollen reference collection. In Studies in the Vegetational History of the British Isles (eds D. Walker and R. G. West), p. 265. Cambridge: Cambridge University Press.

Bates, C. D., Coxon, P. \& Gibbard, P. L. 1978. A new method for the preparation of clay-rich sediment samples for palynological investigation. New Phytologist 81, 459-63.

BIRKs, H. J. B. 1973. Past and Present Vegetation of the Isle of Skye: a Palaeoecological Study. Cambridge: Cambridge University Press, 415 pp.

Bluck, B. J. 1969. Particle rounding in beach gravels. Geological Magazine 106, 1-14.

CARR, A. P. 1971. Experiments on the longshore transport and sorting of pebbles: Chesil Beach, England. Journal of Sedimentary Petrology 41, 1084-104.

Clarke, R.H. 1973. Cainozoic subsidence in the North Sea. Earth and Planetary Science Letters 18, 239-332.

Dobkins, J. E. \& FolK, R. L. 1970. Shape development on Tahiti-Nui. Journal of Sedimentary Petrology 40, 1167-203.

Funnell, B. N., Norton, P. E. P. \& West, R. G. 1979. The Crag at Bramerton, near Norwich, Norfolk. Philosophical Transactions of the Royal Society of London B287, 489-534.

Funnell, B. M. \& West, R. G. 1962. The Early Pleistocene of Easton Bavents, Suffolk. Quarterly Journal of the Geological Society of London 118, 125-41.

FunNell, B. M. \& WeSt, R. G. 1977. Preglacial Pleistocene deposits of East Anglia. In British Quaternary Studies: Recent Advances (ed. F. W. Shotton), pp. 247-65. Oxford: Clarendon Press.

Gibbard, P. L., West, R. G., Zagwijn, W. H., Balson, P. S., Burger, A. W., Funnell, B. M., Jeffery, D. H., De Jong, J., van Kolfschoten, T., Lister, A. M., Meijer, T., Norton, P. E. P., Preece, R. C., Rose, J., Stuart, A. J., Whiteman, C. A. \& Zalasiewicz, J. A. 1991. Early and early Middle Pleistocene correlations in the southern North Sea basin. Quaternary Science Reviews 10, 23-52.

Gibbard, P. L. \& Zalasiewicz, J. A. (eds). 1988. PlioceneMiddle Pleistocene of East Anglia. Quaternary Research Association Field Guide. Cambridge, Quaternary Research Association, $195 \mathrm{pp}$.

Hamblin, R. J. O. 1992. Geological notes and local details for 1:10000 sheet TM 47S W (Thorington); part of 1:50 000 Sheet 191. British Geological Survey Onshore Geology Series Technical Report WA-92-60.

Hamblin, R. J. O., Moorlock, B. S. P., Booth, S. J. Jeffery, D. H. \& Morigi, A. N. 1997. The Red Crag and Norwich Crag formations in eastern Suffolk. Proceedings of the Geologists' Association 108, 11-23.

Hart, B. S. \& Plint, A. G. 1989. Gravelly shoreface deposits: a comparison of modern and ancient facies sequences. Sedimentology 36, 551-7.

Hart, J. K. \& Boulton, G. S. 1991. The interrelationship 
between glaciotectonic deformation and glaciodeposition within the glacial environment. Quaternary Science Reviews 10, 335-50.

Hey, R. W. 1966. Sections in the beach plain deposits of Dungeness, Kent. Geological Magazine 104, 361-70.

Hey, R. W. 1967. The Westleton Beds reconsidered. Proceedings of the Geologists' Association 78, 427-45.

Hey, R. W. 1982. Composition of Pre-Anglian gravels in Norfolk. Bulletin of the Geological Society of Norfolk 32, 51-9.

Hey, R. W., Mathers, S. J. \& Zalasiewicz, J. A. 1988. Wangford. In Pliocene-Middle Pleistocene of East Anglia (eds P. L. Gibbard and J. A. Zalasiewicz) pp. 103-6. Cambridge: Quaternary Research Association.

Kemp, R. A. 1985. The Valley Farm Soil in southern East Anglia. In Soils and Quaternary Landscape Evolution (ed. J. Boardman), pp.179-96. Chichester: Wiley.

Kemp, R. A., Whiteman, C. A. \& Rose, J. 1993. Palaeoenvironmental significance of the Valley Farm and Barham Soils in eastern England. Quaternary Science Reviews 12, 833-48.

Mathers, S. J. \& Zalasiewicz, J. A. 1988. The Red Crag and Norwich Crag Formations of southern East Anglia. Proceedings of the Geologists' Association 99, 261-78.

Mathers, S. J. \& Zalasiewicz, J. A. 1996. A gravel-beachrip-channel system: the Westleton Beds (Pleistocene) of Suffolk, England. Proceedings of the Geologists' Association 107, 57-67.

Murton, J. B., Whiteman, C. A. \& Allen, P. 1995. Involutions in the Middle Pleistocene (Anglian) Barham Soil, eastern England: a comparison with thermokarst involutions from Arctic Canada. Boreas 24, 269-80.

Norton, P. E. P. \& Beck, R. B. 1972. Lower Pleistocene molluscan assemblages and pollen from the Crag at Aldeby (Norfolk) and Easton Bavents (Suffolk). Bulletin of the Geological Society of Norfolk 22, 11-31.

Prestwich, J. 1871. On the structure of the Crag Beds of Suffolk and Norfolk, with some observations on their organic remains. Part 3: The Norwich Crag and Westleton Beds. Quarterly Journal of the Geological Society of London 27, 452-96.

Richards, A. E. (in press) Complex interaction of the British ice-sheet (Anglian Cold Stage) with permafrost. Quaternary Newsletter.

Riding, J. B., Moorlock, B. S. P., Jefferey, D. M. \& Hamblin, R. J. O. 1997. Reworked and indigenous palynomorphs from the Norwich Crag Formation (Pleistocene) of eastern Suffolk: implications for provenance, palaeogeography and climate. Proceedings of the Geologists' Association 108, 25-38.

Rose, J. 1994. Major river systems of central and southern
Britain during the Early and Middle Pleistocene. Terra Nova 6, 435-43.

Rose, J., Allen, P., Kemp, R. A., Whiteman, C. A. \& Owen, N. 1985. Palaeosols and the interpretation of British Quaternary stratigraphy. In Geomorphology and Soils (eds K. Richards, R. Arnett and S. Ellis) pp. 348-75. Hemel Hempstead: Allen and Unwin.

SinCLAIR, J. M. 1990. Flint pebbles of northern provenance in East Anglian Quaternary gravels. Quaternary Newsletter 62, 22-5.

SPENCER, H. E. P. 1967. Field Meeting in the Quaternary of East Suffolk. Proceedings of the Geologists' Association 77, 371-80.

SPENCER, H. E. P. 1971. A contribution to the geological history of Suffolk, part 5. Transactions of the Suffolk Natural History Society 15, 279-357.

Stuart, A. J. 1982. Pleistocene Vertebrates in the British Isles. London: Longman. 212 pp.

Taylor, R. L. S. \& Smalley, I. J. 1969. Why Britain tilts. Science 1975, 54-9.

West, R. G. 1961. Vegetational history of the Royal Society borehole at Ludham, Norfolk. Philosophical Transactions of the Royal Society of London B115, 437-53.

West, R. G. 1977. Pleistocene Geology and Biology: with Especial Reference to the British Isles, 2nd ed. London: Longman, $440 \mathrm{pp}$.

West, R. G. 1980. The Pre-Glacial Pleistocene of the Norfolk and Suffolk Coasts. Cambridge: Cambridge University Press, 203 pp.

West, R. G., Funnell, B. M. \& Norton, P. E. P. 1980. An early Pleistocene cold marine episode in the North Sea: pollen and floral assemblages at Covehithe, Suffolk, England. Boreas 9, 1-10.

West, R. G. \& Norton, P. E. P. 1974. The Icenian Crag of south-east Suffolk. Philosophical Transactions of the Royal Society of London B268, 1-28.

Zalasiewicz, J. A. \& Gibbard, P. L. 1988. The Pliocene to Early Middle Pleistocene of East Anglia: an overview. In Pliocene-Middle Pleistocene of East Anglia (eds P. L. Gibbard and J. A. Zalasiewicz). Cambridge: Quaternary Research Association.

Zalasiewicz, J. A., Gibbard, P. L., Peglar, S. M., Funnell, B. M., Catt, J. A., Harland, R., Long, P. E. \& Austin, T. J. F. 1991. Age and relationships of the Chillesford Clay (early Pleistocene: Suffolk, England). Philosophical Transactions of the Royal Society of London B333, 8-100.

Zalasiewicz, J. A., Hughes, M. J., Gibbard, P. L., Peglar, S. M., Harland, R., Nicholson, R. A., Boulton, G. S., Cambridge, P. \& Wealthall, G. P. 1988. Stratigraphy and palaeoenvironments of the Red Crag and Norwich Crag formations between Aldeburgh and Sizewell, Suffolk, England. Philosophical Transactions of the Royal Society of London B322, 221-72. 